\title{
COMPARATIVE STUDY ON STATIC AND DYNAMIC ANALYSIS OF STRUCTURES
}

\author{
Meleka, N. ${ }^{1}$, Hekal, G. ${ }^{2}$, Rizk, Ashraf. ${ }^{3}$ \\ Civil Engineering Department, Faculty of Engieering, Menoufiya University, EGYPT
}

\begin{abstract}
: -
As the modern buildings have been gotten taller and narrower than before, the structural engineers have to perform both static and dynamic analysis for seismic loads that may affect on structures in order to make sure of the safety verifications and the optimal design requirements. The two common methods that always used for structural analysis against lateral loads are equivalent static method and response spectrum analysis. However, some different limits and restrictions for using the first method are stated by the universal design codes. This research studies the differences between the two methods through the results of seismic analysis by using Egyptian code of practice 2012, European Code 8: 2004 and Uniform Building Code 1997. It has been concluded that the equivalent static analysis method always gives higher results for drifts and overturning moments than those of response spectrum analysis method in case of using the aforementioned three design codes.
\end{abstract}

Keywords: - Seismic analysis, response spectrum method, equivalent static method

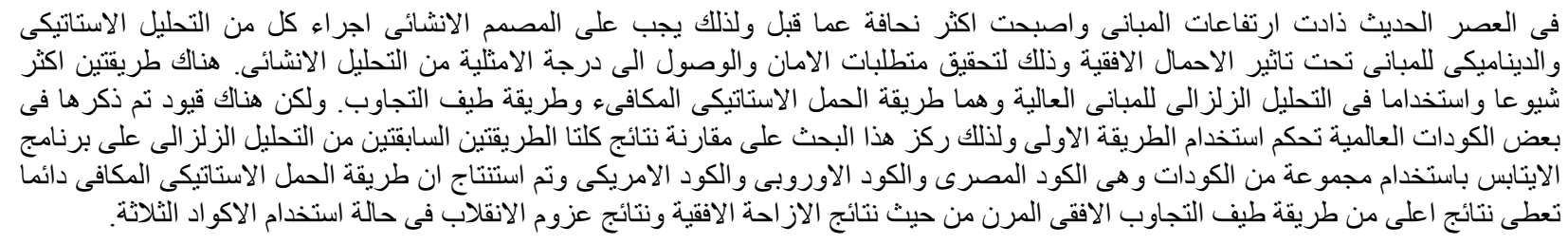

\section{Introduction:-}

Seismic design of tall buildings is primarily concerned with structural safety during major earthquake; however, serviceability, human comfort and the potential for economic loss are also of concern. Seismic analysis requires an understanding of the structural performance under large inelastic deformations. Biswas, R. [4] demonstrated the accuracy and the exactness of equivalent static analysis in comparison with the most commonly adopted method, response spectrum analysis. Mahmoud, S., and Abdallah, W., [5], evaluated the seismic performance of an existing shear wall residential building located in Cairo using response spectrum analysis and equivalent static force methods in the seismic analysis. Srikanth, B., and Ramesh, V., [6] also compared the two different methods according IS code. Then, they concluded that there are a significant differences in building's responses obtained using the two methods. Bagheri, B., et al, [7] compared the results of drift at top for 20-storey $\mathrm{RC}$ building, which obtained from equivalent static method, response spectrum method and time history method by using elcentro earthquake 1940. The main objective of this paper is to study the limitations of using equivalent static method in case of Egyptian Code of Practice, ECP 2012 [1], European Code 8: 2004, EC8: 2004 [2], and Uniform Building Code, UBC1997[3].

\section{Research methodology:-}

In the present study, regular shear wall buildings with seven different level of heights, started by 5 stories and gradually increased to pass 10,14, 17, 20, 24 and 30 stories with the same plane are modeled using software packages ETABS. Each case is analyzed for the same lateral loads using the two different analysis methods, the static and dynamic analysis methods. Both of the two methods are based on elastic response spectrum curve using ECP 2012, EC8: 2004 and UBC 1997. For the aim of comparison, the results of displacements at top and the differences between the results of the two methods are tabulated versus each case. Based on the differences between the results of the two methods, the limitations of using linear static analysis method in seismic analysis can be concluded for each design code.

\section{Building Description:-}

The structural system that adopted for the studied cases is shear wall system with central core and four shear walls in $\mathrm{x}$-direction and six shear walls $y$-direction whereas the adopted schematic plane for this study is shown in Fig. (1). 


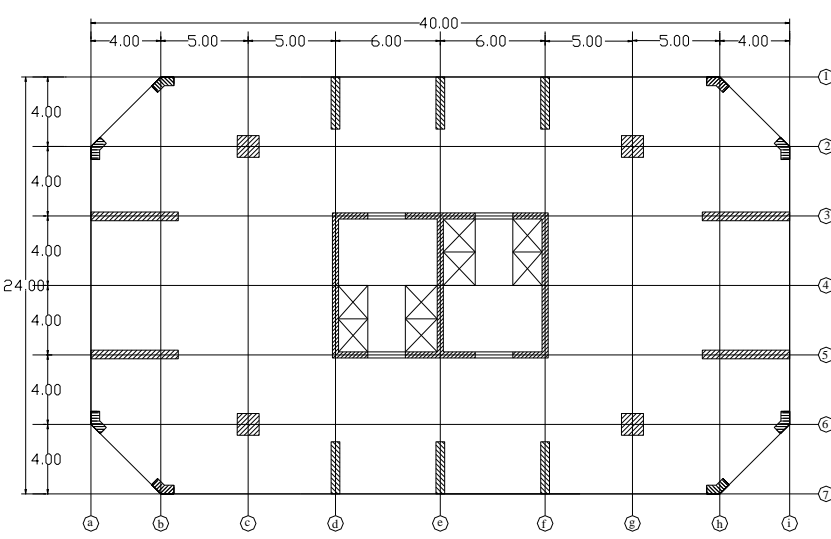

Figure (1): Schematic plane for shear wall system

This plane is repeated for all floors in all buildings without any changes or setbacks. The seven levels of heights for the shear wall system are shown in Fig. (2).

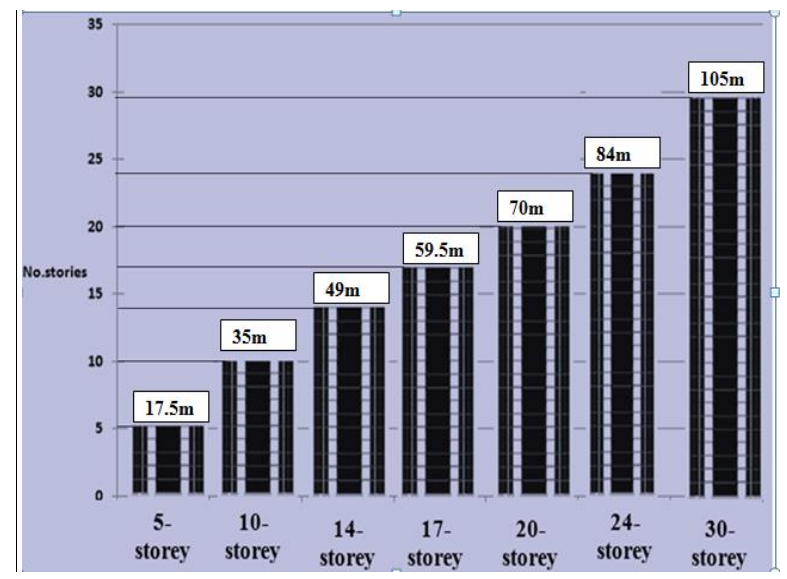

Figure (2): The studied buildings

The cross sectional areas for both columns and shear walls are designed against the determined ultimate gravity loads at the base for each building by using the ultimate load equation that stated in ECP 2012, [1], as the following

$\mathrm{P}_{\mathrm{ult}}=0.35 \mathrm{f}_{\mathrm{cu}} \mathrm{Ac}+0.67 \mathrm{f}_{\mathrm{y}} \mathrm{As}$

Eq. (1)

Where

$\mathrm{P}_{\text {ult }} \quad$ Ultimate load calculated at base

$\mathrm{A}_{\mathrm{C}} \quad$ Area of concrete for section under study

$\mathrm{f}_{\mathrm{cu}} \quad$ Ultimate compressive strength for concrete

$\mathrm{A}_{\mathrm{S}} \quad$ Area steel in cross section

$\mathrm{F}_{\mathrm{y}} \quad$ Yield stress for the reinforced bars

\section{General Assumption for Primary Design of Vertical Elements:-}

1) The ultimate load, $P_{\text {ult }}$ is calculated for each vertical member by aggregating the supposed gravity loads above the foundation level based on the load combination, $\mathrm{P}_{\mathrm{ult}}=1.4 \mathrm{DL}+1.6 \mathrm{LL}$
2) This pattern is applied for each system separately

3) Floor thickness, ts is considered $25 \mathrm{~cm}$ for all buildings

4) Concrete cover for all vertical elements is assumed $4.0 \mathrm{~cm}$

5) Compressive strength for concrete, $f_{c u}$ is assumed $350 \mathrm{~kg} / \mathrm{cm}^{2}$ for all concrete elements

6) Live load is assumed $300 \mathrm{~kg} / \mathrm{m}^{2}$ uniformly distributed over the entire floor area

7) Total uniform dead load is assumed equal (flooring cover $150 \mathrm{~kg} / \mathrm{m}^{2}+$ walls and partitions $400 \mathrm{~kg} / \mathrm{m}^{2}=$ $550 \mathrm{~kg} / \mathrm{m}^{2}$ )

8) Thickness of core wall is considered 20, 25, 27, 29, 31,33 and $35 \mathrm{~cm}$ for the $5,10,14,17,20,24$, and 30 -storey buildings respectively

9) For each building the cross sectional area for vertical elements is considered constant through the entire height of the building

10) Yield strength for high tensile steel, $f_{y}$ is considered $3600 \mathrm{~kg} / \mathrm{cm}^{2}$ and the area of steal inside the section is allowed to equal $0.2 \%$ of area concrete for compression members

Substituting with the previous assumptions in the ultimate load formula Eq. (1), the area concrete of the any section can be given as a function of load as the following:

$$
\mathrm{P}_{\mathrm{ult}}=170.74 \mathrm{Ac}
$$

\section{Methods of Analyses:-}

The adopted methods for seismic analysis are equivalent static method and response spectrum method

\section{Equivalent Static Method:-}

Seismic analysis by this method is considered sufficient for regular, low to

medium-rise buildings. This is permitted in most codes of practice. It begins with an estimation of base shear load and its distribution on each story calculated by using formulas given in the considered codes, [1-3]. However, for high-rise buildings where second and higher modes can be important, or buildings with torsional effects, the implementation of equivalent static method is considered not sufficient and complex methods such as response spectrum method and time history method are required used in these circumstances.

The specified Seismic Parameters for Equivalent Static Method are summarized for each code as given in Table (1) 
Table (1): Parameters of equivalent static method

\begin{tabular}{|c|c|}
\hline code & Considered seismic parameters \\
\hline 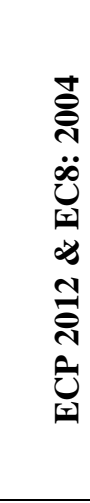 & $\begin{array}{l}\text { - } \text { Response spectrum type (1) } \\
\text { - Soil class (B) } \\
\text { - } \text { TB, TC and TD are } 0.05,0.25 \text { and } 1.2 \\
\text { respectively } \\
\text { - Response modification factor, } \mathrm{R}=4.5,4 \\
\text { for ECP 2012, EC8: } 2004 \text { respectively } \\
\text { - Ground acceleration, ag = 0.125g and } \\
0.15 \mathrm{~g} \text { for ECP 2012, EC8: } 2004 \\
\text { respectively } \\
\text { - Correction factor, } \eta=1 \\
\text { - Importance factor, } \mathrm{\gamma}=1 \\
\text { - Time period, } \mathrm{T}=0.05 \mathrm{H}^{0.75}\end{array}$ \\
\hline$\frac{\hat{\sigma}}{\hat{\sigma}}$ & $\begin{array}{l}\text { - Seismic zone (2A) with seismic zone } \\
\text { factor, } 0.15 \\
\text { - Soil profile }\left(\mathrm{S}_{\mathrm{C}}\right) \\
\text { - Seismic coefficients, } \mathrm{Ca}=0.18, \mathrm{Cv}=0.25 \\
\text { - Time period, } \mathrm{T}=\mathrm{CtH}^{0.75},(\mathrm{Ct}=0.035) \\
\text { - Over strength factor, } \mathrm{R}=4.5 \\
\text { - Importance factor, } \mathrm{V}=1\end{array}$ \\
\hline
\end{tabular}

\section{Response Spectrum Method:-}

A plot of maximum dynamic response, such as accelerations versus the natural periods of the building gives us an acceleration response spectrum.

This curve is determined in accordance with the site conditions such as soil profile, damping factor and return period of maximum capable earthquake.

\section{What ETABS does?}

Is that, it calculates the maximum acceleration versus the natural period of structure then, the maximum acceleration is incorporated with seismic weight and other seismic parameters that have been defined to the program according to a certain code. By performing the analysis, the base shear is determined, distributed through the height and affect horizontally tried to bend the structure over the ground.

The specified elastic response spectrum curve that adopted for response spectrum analysis versus each code are summarized in Table (2), whereas the seismic parameters in Table (1) are taken in mind.
Table (2): Specified Response Spectrum Curves

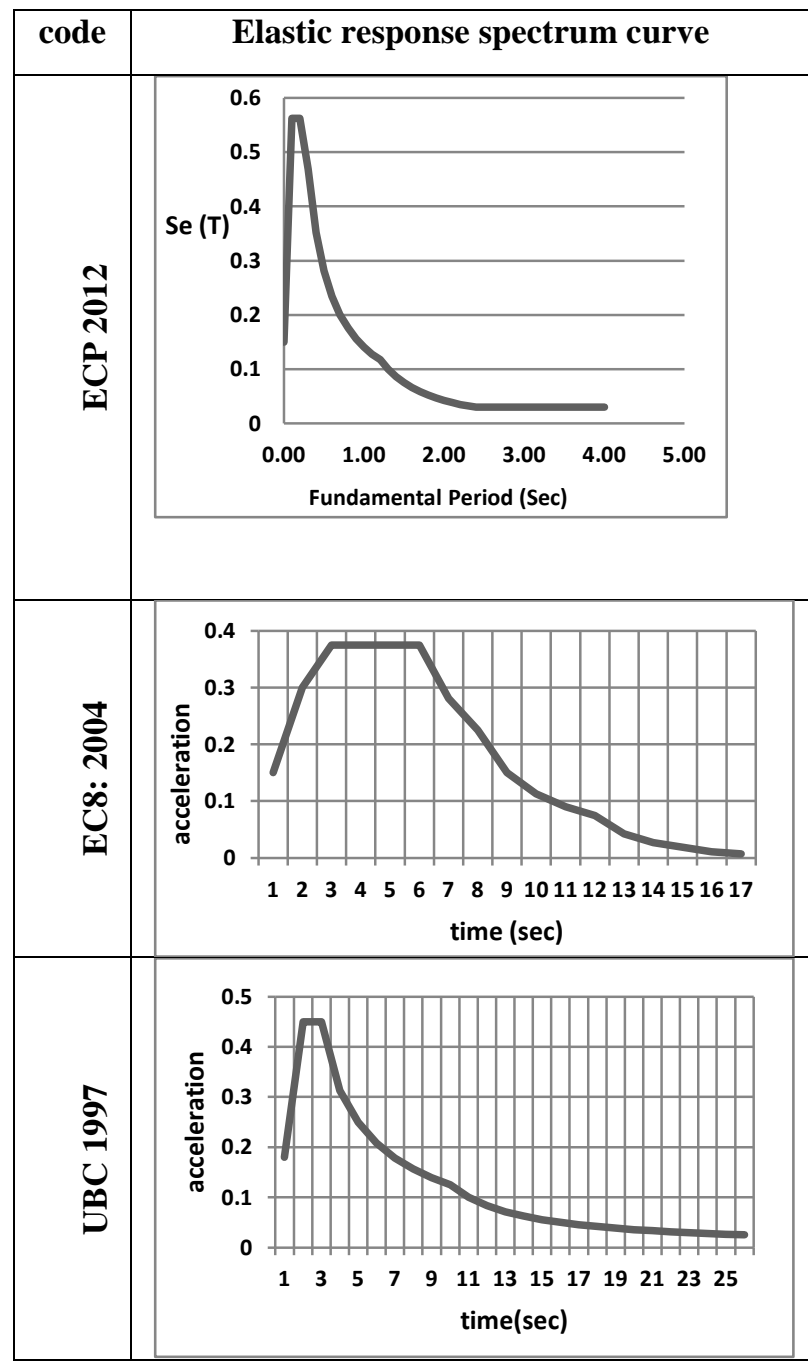

To convert these curves from elastic state to the design state, a correction factor equal $(9.81 / \mathrm{R})$ is multiplied by their case of loading.

\section{General Assumptions for Modeling and Analysis:-}

1) Orientations and spans for vertical elements are considered constant through the height

2) Service core area is considered the same for all cases

3) The beam that connects the core walls, is considered $35 \times 100 \mathrm{~cm}$ through the entire height of the building

4) Story height is considered $3.50 \mathrm{~m}$ for all cases

5) Hall and service core area are connected with horizontal rigid diaphragms

6) Service core area is defined as a pier section in ETABS 
7) All cases are considered rested on fixed foundation

8) Material specifications for reinforced concrete are the same for all cases

9) The applied lateral loads are represented only in seismic loads

10) The assigned mass source to the program in order to measure the seismic weight is commonly used as a combination of total dead loads plus $50 \%$ of live loads

11) Constant percents from the full inertia for all vertical and horizontal elements are assumed to participate in seismic resistance in order to take the effects of cracking into consideration

\section{Analysis and Results: -}

The seven cases have been modeled and analyzed using the two considered methods then the results of both displacements at top and overturning moments at base are obtained and tabulated versus each case and code

\section{a. Results of Displacement at Top}

Tables (3, 4 and 5) give the results of displacements at top versus each case for ECP 2012, EC8: 2004 and UBC 1997 respectively

Table (3): Drift values for both static and dynamic analysis by ECP 2012

\begin{tabular}{|l|l|l|l|}
\hline Buildings & $\begin{array}{l}\text { Static } \\
\text { analysis }\end{array}$ & $\begin{array}{l}\text { Dynamic } \\
\text { analysis }\end{array}$ & $\begin{array}{l}\text { Difference } \\
\text { ratio\% }\end{array}$ \\
\hline 5-storey & 0.70 & 0.60 & 21.00 \\
\hline 10-storey & 2.01 & 1.58 & 21.39 \\
\hline 14-storey & 4.03 & 3.12 & 22.58 \\
\hline 17-storey & 6.87 & 5.21 & 24.16 \\
\hline 20-storey & 10.8 & 8.07 & 25.28 \\
\hline 24-storey & 15.2 & 11.3 & 25.66 \\
\hline 30-storey & 34.9 & 25.3 & 27.51 \\
\hline
\end{tabular}

Table (4): Drift values for both static and dynamic analysis by EC8:2004

\begin{tabular}{|l|l|l|l|}
\hline Buildings & $\begin{array}{l}\text { Static } \\
\text { analysis }\end{array}$ & $\begin{array}{l}\text { Dynamic } \\
\text { analysis }\end{array}$ & $\begin{array}{l}\text { Difference } \\
\text { ratio\% }\end{array}$ \\
\hline 5-storey & 1.53 & 1.25 & 18.30 \\
\hline 10-storey & 3.24 & 2.66 & 17.9 \\
\hline 14-storey & 5.06 & 4.11 & 18.77 \\
\hline 17-storey & 8.13 & 5.4 & 33.58 \\
\hline 20-storey & 12.8 & 6.71 & 47.58 \\
\hline 24-storey & 21.4 & 7.54 & 64.77 \\
\hline 30-storey & 41.3 & 7.74 & 81.26 \\
\hline
\end{tabular}

Table (5): Drift values for both static and dynamic analysis by UBC 1997

\begin{tabular}{|l|l|l|l|}
\hline Buildings & $\begin{array}{l}\text { Static } \\
\text { analysis }\end{array}$ & $\begin{array}{l}\text { Dynamic } \\
\text { analysis }\end{array}$ & $\begin{array}{l}\text { Difference } \\
\text { ratio\% }\end{array}$ \\
\hline 5-storey & 1.51 & 1.26 & 16.56 \\
\hline 10-storey & 3.35 & 2.57 & 23.28 \\
\hline 14-storey & 5.38 & 4.03 & 25.09 \\
\hline 17-storey & 7.24 & 5.36 & 25.97 \\
\hline 20-storey & 9.6 & 6.67 & 30.52 \\
\hline 24-storey & 16.4 & 8.62 & 47.44 \\
\hline 30-storey & 32 & 12 & 62.5 \\
\hline
\end{tabular}

Figures (3, 4 and 5) represent the values of displacements at top versus each case for ECP 2012, EC8: 2004 and UBC 1997 respectively

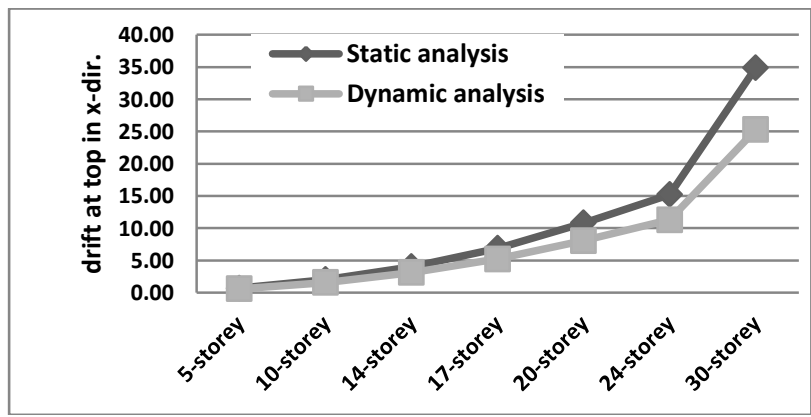

Figure (3): Drift values for both static and dynamic analysis according to ECP 2012

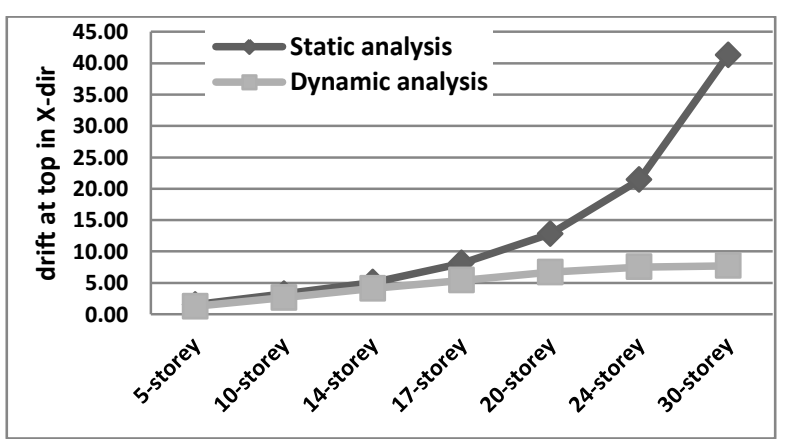

Figure (4): Drift values for both static and dynamic analysis according to EC8: 2004 


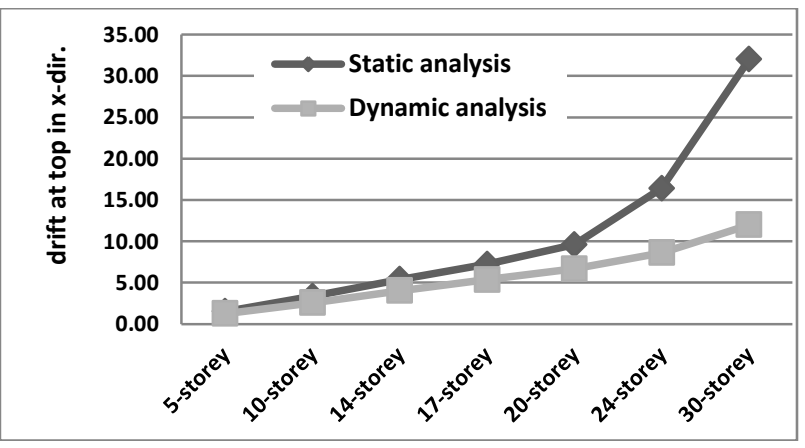

Figure (5): Drift values for both static and dynamic analysis according to UBC 1997

Figure (6) represent the difference ratios between the values of displacement at top for both static and dynamic analysis versus each case and code

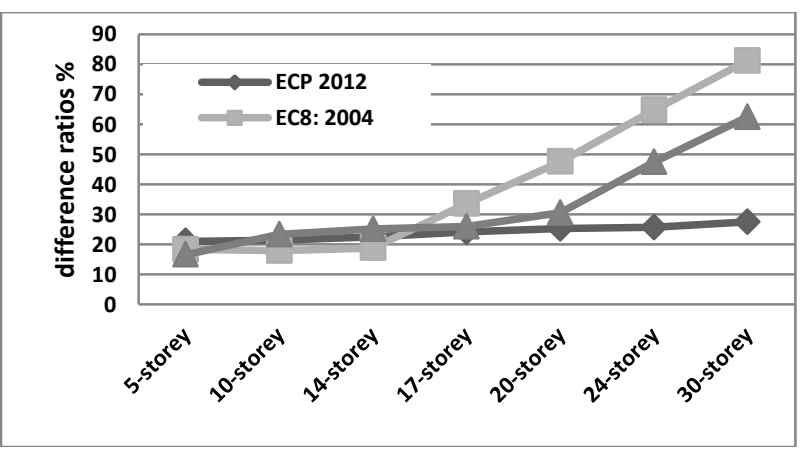

Figure (6): Difference ratio between drifts at top for static and dynamic analyses

\section{b. Results of Overturning Moments at Base:-}

Tables (6, 7 and 8) give the results of overturning moments at base versus each case for ECP 2012, EC8: 2004 and UBC 1997 respectively

Table (6): BM at base for both static and dynamic analysis for each case by ECP 2012

\begin{tabular}{|c|c|c|c|}
\hline \multirow[b]{2}{*}{ Buildings } & \multicolumn{2}{|c|}{ BM at base (t.m $\left.\times 10^{3}\right)$} & \multirow[b]{2}{*}{$\begin{array}{l}\text { Difference } \\
\text { ratio\% }\end{array}$} \\
\hline & $\begin{array}{l}\text { Static } \\
\text { analysis }\end{array}$ & $\begin{array}{l}\text { Dynamic } \\
\text { analysis }\end{array}$ & \\
\hline 5 -storey & 3.41 & 2.76 & 19.06 \\
\hline 10 -storey & 8.65 & 7.22 & 16.532 \\
\hline 14-storey & 14.4 & 12.1 & 15.972 \\
\hline 17 -storey & 22.6 & 17.9 & 20.796 \\
\hline 20 -storey & 34.7 & 25.1 & 27.666 \\
\hline 24-storey & 52.8 & 32.5 & 38.447 \\
\hline 30-storey & 92.5 & 52.7 & 43.027 \\
\hline
\end{tabular}

Table (7): BM at base for both static and dynamic analysis for each case by EC8: 2004

\begin{tabular}{|c|c|c|c|}
\hline \multirow[b]{2}{*}{ Buildings } & \multicolumn{2}{|c|}{ BM at base $\left(\mathrm{t} . \mathrm{m} \times 10^{3}\right)$} & \multirow[b]{2}{*}{$\begin{array}{l}\text { Difference } \\
\text { ratio\% }\end{array}$} \\
\hline & $\begin{array}{l}\text { Static } \\
\text { analysis }\end{array}$ & $\begin{array}{l}\text { Dynamic } \\
\text { analysis }\end{array}$ & \\
\hline 5-storey & 7.56 & 6.08 & 19.57 \\
\hline 10-storey & 15.6 & 12.4 & 20.513 \\
\hline 14-storey & 20.7 & 15.7 & 24.155 \\
\hline 17-storey & 29.2 & 17.9 & 38.699 \\
\hline 20-storey & 41.3 & 20 & 51.574 \\
\hline 24-storey & 60.6 & 19.4 & 67.987 \\
\hline 30-storey & 98.2 & 16.2 & 83.503 \\
\hline
\end{tabular}

Table (8): BM at base for both static and dynamic analysis for each case by UBC 1997

\begin{tabular}{|c|c|c|c|}
\hline \multirow[b]{2}{*}{ Buildings } & \multicolumn{2}{|c|}{ BM at base $\left(\mathrm{t} . \mathrm{m} \times 10^{3}\right)$} & \multirow[b]{2}{*}{$\begin{array}{l}\text { Difference } \\
\text { ratio\% }\end{array}$} \\
\hline & $\begin{array}{l}\text { Static } \\
\text { analysis }\end{array}$ & $\begin{array}{l}\text { Dynamic } \\
\text { analysis }\end{array}$ & \\
\hline 5-storey & 7.47 & 6.13 & 17.93 \\
\hline 10-storey & 16 & 11.8 & 26.25 \\
\hline 14-storey & 21.6 & 15.3 & 29.167 \\
\hline 17-storey & 25.4 & 17.7 & 30.315 \\
\hline 20-storey & 29.8 & 19.7 & 33.893 \\
\hline 24-storey & 44.4 & 22.4 & 49.55 \\
\hline 30-storey & 72.6 & 26 & 64.187 \\
\hline
\end{tabular}

Figures (7, 8 and 9) represent the values of displacements at top versus each case for ECP 2012, EC8: 2004 and UBC 1997 respectively

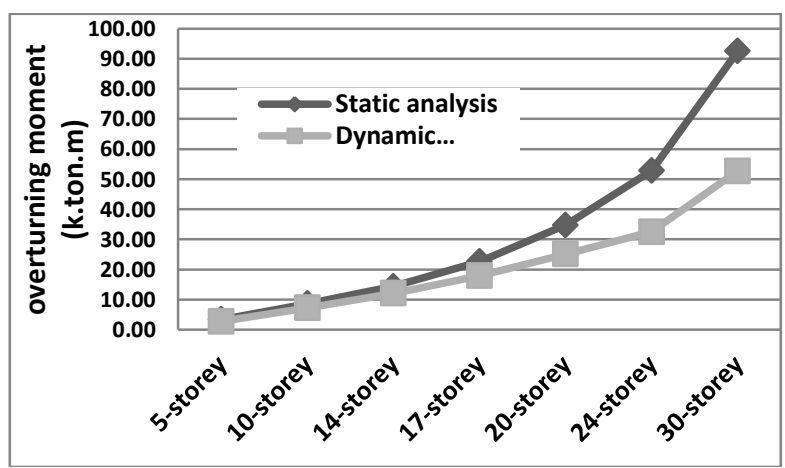

Figure (7): BM at base for both static and dynamic analysis according to ECP 2012 


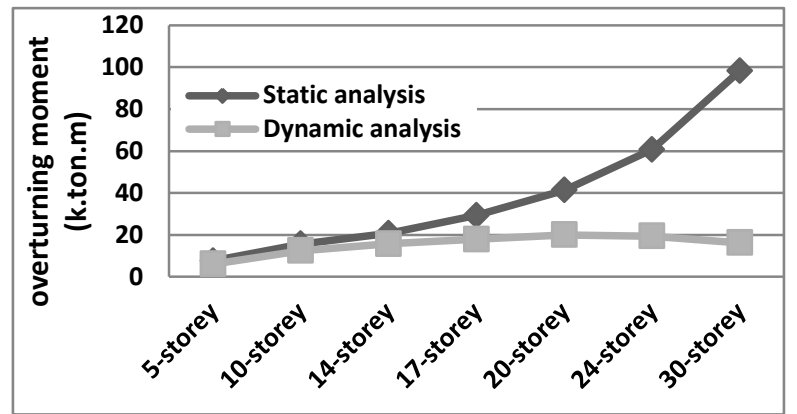

Figure (8): BM at base for both static and dynamic analysis according to EC8: 2004

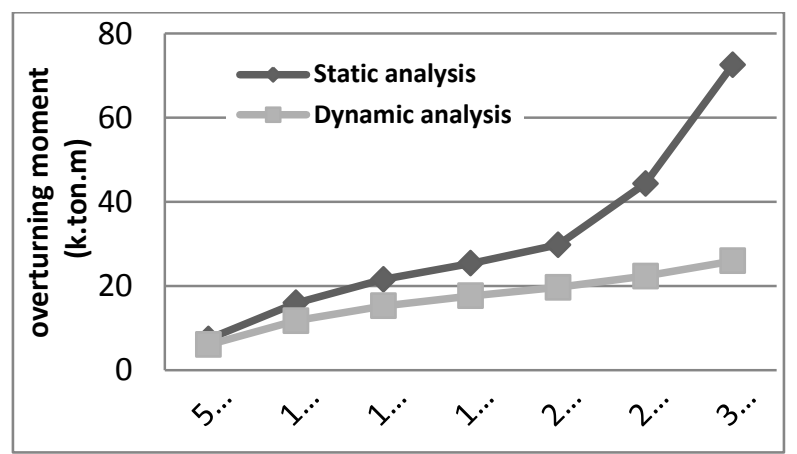

Figure (9): BM at base for both static and dynamic analysis according to UBC 1997

Figure (10) represent the difference ratios between the values of overturning moments at base for both static and dynamic analysis versus each case and code

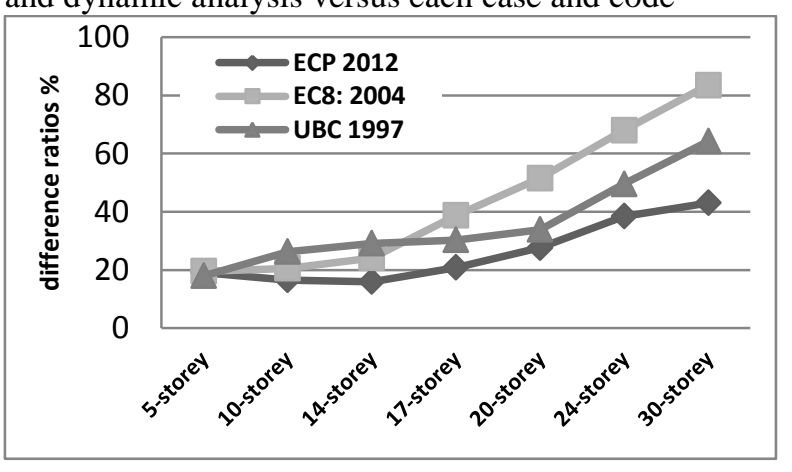

Figure (10): Difference ratio between BM at base for static and dynamic analyses

\section{Discussion of Results:-}

It is seen from the previous figures that the values of both drifts at top and overturning moments obtained by response spectrum analysis and static analysis are closed to each other especially for low-rise buildings. While, static analysis gives higher values for drifts at top and overturning moments rather than the other method of analysis, especially in high levels.

Regarding the results of ECP 2012, Table (3) and Fig. (3) Show that the differences between the results of drift for both static and dynamic are almost insignificant. On the other hand, Table (6) and Fig. (7) Show that the differences between the results of overturning moment are largely increased especially from the 20-storey building whereas, the difference ratio in the 17 -storey building is $20.79 \%$ then the percent increased to be $27.66 \%, 38.44 \%$ and $43.02 \%$ for the 20, 24 and 30-storey building respectively.

Regarding the results of EC8: 2004, Table (4,7) and Fig. $(4,8)$ Show that the differences between the results in the first three buildings are insignificant in both results relevant to drifts at top and overturning moments at base. On the other hand, the differences between the results in the last four buildings are largely increased with the height. Whereas, the differences ratio in the 14-storey building for drift at top and overturning moments are $15.97 \%$ and $24.15 \%$ respectively then the ratios of drift at top increased to be $20.8 \%, 27.66 \%, 38.44 \%$ and $43.02 \%$ similarly, the ratios of overturning moments increased to be $38.70 \%$, $51.57 \%, 67.98 \%$ and $83.5 \%$ for the last four heights respectively.

Regarding the results of UBC 1997, Table $(5,8)$ and Fig. $(5,9)$ Show that that the differences between the results in the first five buildings are insignificant in both results relevant to drifts at top and overturning moments. On the other hand, the differences between the results in the last two buildings in both drifts at top and overturning moments are largely increased with the height. Whereas, the differences between the results in the 20-storey building for drift at top and overturning moments are $30.52 \%$ and $33.89 \%$ respectively then the ratios increased to be $47.44 \%$ and $62.5 \%$ in case of drift at top similarly, the ratios increased to be $49.55 \%$ and $64.18 \%$ in case of overturning moments for the last four heights respectively.

\section{Conclusions:-}

1) The equivalent static method can be used as same as the response spectrum analysis method for seismic analysis of low-rise building however for medium to high-rise building the equivalent static method should not be used because it gives higher values for drifts at top and overturning moments rather than other methods of analysis, especially in higher stories

2) In ECP 2012, the equivalent static method may be applied on buildings with less than $60 \mathrm{~m}$ height. While, In EC8: 2004, the equivalent static method may be applied on buildings less than 40m height. On the other hand, UBC 1997 may permit using it up to $70 \mathrm{~m}$ height. Thereby using equivalent static method in seismic analysis above these heights will be accompanied by uneconomic values for design 


\section{References:-}

[1] "Egyptian Code of Practice for Calculating Loads and Forces in Structural and Building Works", National Research Center for Housing, Building and Physical Planning, 2012

[2] "European Code 8", Design of Structures for Earthquake Resistance Part 1: general rules, seismic actions and rules for buildings, Dec. 2003

[3] Uniform Building Code "Structural Engineering Design Provisions", chapter 16, Earthquake Design, Vol:2,1997

[4] Biswas, R., "Dynamic Analysis of High-Rise Flat Plate Building with Different Retrofitting Systems", European Academic Research, Vol:1, Issue No: 11, February 2014
[5] Mahmoud, S., and Abdallah, W., "Response Analysis of Multi-Storey RC Buildings under Equivalent Static and Dynamic Loads According to Egyptian Code", International Journal of Civil and Structural Engineering Research, ISSN 2348-7607, Vol:2, Issue No:1, pp: (79-88), April 2014 - Sep. 2014

[6] Srikanth, B., and Ramesh, V., "Comparative Study of Seismic Response for Seismic Coefficient and Response Spectrum Methods", Journal of Engineering Research and Applications ISSN: 2248-9622, Vol:3, Issue No:5, Sep-Oct. 2013, pp.1919-1924

[7] Bagheri, B., Firoozabad, E., and Yahyaei, M., " Comparative Study of the Static and Dynamic Analysis of Multi-Storey Irregular Building", World Academy of Science, Engineering and Technology Vol:6, Nov. 2012 
Meleka, N., Hekal, G., Rizk, Ashraf. " COMPARATIVE STUDY ON STATIC AND DYNAMIC ANALY...." 